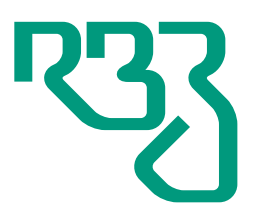

\section{Revista}

Brasileira de

Zootecnia

Brazilian Journal of Animal Science

ISSN 1806-9290

www.rbz.org.br

\title{
Polymorphism of the BCO2 gene and the content of carotenoids, retinol, and $\alpha$-tocopherol in the liver and fat of rabbits
}

\author{
Janusz Strychalski ${ }^{*}$ (D), Andrzej Gugołek ${ }^{1}$ (D), Paweł Brym² (iD), Zofia \\ Antoszkiewicz $^{3}$ (D), Iwona Chwastowska-Siwiecka ${ }^{4}$ (iD) \\ ${ }^{1}$ University of Warmia and Mazury, Faculty of Animal Bioengineering, Department of \\ Fur-bearing Animal Breeding and Game Management, Olsztyn, Poland. \\ ${ }^{2}$ University of Warmia and Mazury, Faculty of Animal Bioengineering, Department of \\ Animal Genetics, Olsztyn, Poland. \\ ${ }^{3}$ University of Warmia and Mazury, Faculty of Animal Bioengineering, Department of \\ Animal Nutrition and Feed Science, Olsztyn, Poland. \\ ${ }^{4}$ University of Warmia and Mazury, Faculty of Animal Bioengineering, Department of \\ Commodity Science and Animal Raw Material Processing, Olsztyn, Poland.
}

\author{
*Corresponding author: \\ janusz.strychalski@uwm.edu.pl \\ Received: October 19, 2018 \\ Accepted: February 28, 2019 \\ How to cite: Strychalski, J.; Gugołek, A.; Brym, P.; \\ Antoszkiewicz, Z. and Chwastowska-Siwiecka, I. \\ 2019. Polymorphism of the BCO2 gene and the \\ content of carotenoids, retinol, and $\alpha$-tocophero \\ in the liver and fat of rabbits. Revista Brasileira \\ de Zootecnia 48:e20180243. \\ https://doi.org/10.1590/rbz4820180243 \\ Copyright: This is an open access article \\ distributed under the terms of the \\ Creative Commons Attribution License \\ (http://creativecommons.org/licenses/by/4.0/), \\ which permits unrestricted use, distribution, \\ and reproduction in any medium, provided the \\ original work is properly cited.
}

\begin{abstract}
The study was carried out to evaluate the effect of AAT-deletion mutation at codon 248 of the BCO2 gene on the content of lutein, $\beta$-carotene, retinol, and $\alpha$-tocopherol in the liver and fat of crossbred rabbits. The experimental animals comprised 90 rabbits, produced by reciprocal crossing between ins/del heterozygous parents of Flemish Giant, New Zealand Red, and Termond White breeds. All rabbits in the litter were genotyped, given the same diet, and finally slaughtered at $140 \mathrm{~d}$ of age. It was found that regardless of the mating scheme employed, all del/del homozygotes had the yellow fat trait, whereas heterozygous and homozygotes animals without the AAT deletion (ins/ins) developed white fat. Lutein concentration in fat was over 13-fold higher in rabbits carrying a homozygous AAT-deletion than in the remaining animals. A codon deletion in the $\mathrm{BCO} 2$ gene also contributes to an increase in the concentrations of $\beta$-carotene and $\alpha$-tocopherol in the adipose tissue of rabbits. However, no differences were observed in the content of the analyzed components between heterozygous and homozygous rabbits without the deletion.
\end{abstract}

Keywords: adipose tissue, carotenoids, rabbit, vitamins

\section{Introduction}

Carotenoids can be divided into hydrocarbon carotenoids, i.e., carotenes (e.g., $\beta$-carotene and lycopene) and oxygenated carotenoids, i.e., xanthophylls (e.g., lutein and zeaxanthin). Carotenoids are cleaved by homologous enzymes $\mathrm{BCO} 1$ ( $\beta$-carotene 15,15'-monooxygenase 1 ) and $\mathrm{BCO} 2$ ( $\beta$-carotene $9 ', 10$ '-oxygenase). BCO2 is characterized by broader substrate specificity than BCO1. BCO1 is a cytoplasmic protein, and $\mathrm{BCO} 2$ is found in the mitochondria (Amengual et al., 2011). Provitamin A carotenoids, such as $\beta$-carotene, $\alpha$-carotene, and $\beta$-cryptoxanthin, may be cleaved by either BCO1 or $\mathrm{BCO} 2$. However, the activity of $\mathrm{BCO} 2$ is higher towards non-provitamin A carotenoids such as lycopene, lutein, and zeaxanthin (Mein et al., 2011). BCO2 cleaves carotenoids, yielding apo-10'-carotenals and ionones, whose functions have not been fully elucidated to date (Lietz et al., 2012).

In mammalian species such as cattle, sheep, and mice, mutations in the BCO2 gene impair the function of protein that breaks down non-provitamin A carotenoids (Tian et al., 2010; Våge and Boman, 2010; Amengual et al., 2011). As a result, carotenoids are stored in animal tissues, giving them a yellow color. 
A carotenoid-rich diet intensifies yellow pigmentation (Kotake-Nara and Nagao, 2011). In sheep, yellow fat is an autosomal recessive trait, whereas in cattle, the inheritance pattern of the yellow fat phenotype is far more complex (Tian et al., 2012). In rabbits, the presence of yellow fat is a simple Mendelian recessive trait. We compared the phenotypes - without genotyping - of New Zealand Red rabbits and found that yellow-fat rabbits, in comparison with their white-fat counterparts, have higher levels of lutein, $\beta$-carotene, retinol (one of the major forms of vitamin A), and $\alpha$-tocopherol (the most biologically active form of vitamin $\mathrm{E}$ ) in perirenal fat and higher lutein concentrations in the liver (Strychalski et al., 2016). We reported for the first time the presence of a homozygous AAT in-frame deletion at codon 248 of the BCO2 gene in three yellow-fat rabbits (Strychalski et al., 2015). This mutation resulted in the absence of asparagine in the $\mathrm{BCO} 2$ enzyme.

The relationships between genotypes associated with the AAT in-frame deletion in the $\mathrm{BCO} 2$ gene and the presence of biologically active compounds in selected tissues of rabbits have not yet been determined. The current study was carried out to evaluate the effect of $\mathrm{BCO} 2$ genotypes on the content of lutein, $\beta$-carotene, retinol, and $\alpha$-tocopherol in the liver and fat of crossbred rabbits.

\section{Material and Methods}

The animal protocol used in this study was approved by the local Institutional Animal Care and Use Committee in Olsztyn, Poland (Latitude: $53^{\circ} 74^{\prime} 84^{\prime \prime} \mathrm{N}$; Longitude: $20^{\circ} 44^{\prime} 73 " \mathrm{E}$ ). The experiment was conducted in accordance with EU Directive 2010/63/EU on the protection of animals used for scientific purposes.

The experimental animals comprised 90 rabbits, produced by reciprocal crossing between ins/del heterozygous parents of Flemish Giant (FG), New Zealand Red (NZR), and Termond White (TW) breeds (Figure 1). BCO2 indel genotyping employed in the study was performed according to the PCR-RFLP method as described previously (Strychalski et al., 2015). The gene variant with the AAT in-frame deletion at codon 248 of the BCO2 gene is subsequently referred to in the text as "del", and the variant without deletion is referred to as "ins". One rabbit of each genotype (ins/ins, ins/del, del/del) was selected from every litter, maintaining a sex ratio.

Rabbits were kept in individual wire-mesh flat-deck cages $(0.5 \times 0.6 \times 0.4 \mathrm{~m})$ in a closed experimental pavilion. All animals received the same pelleted diets for domestic rabbits (Table 1). The experiment began at $45 \mathrm{~d}$ of age (weaning) and ended at $140 \mathrm{~d}$ of age.

Rabbits were fasted for $24 \mathrm{~h}$, weighed, and sacrificed in accordance with the recommendations for euthanasia of experimental animals (they were stunned and bled, and the entire operation took
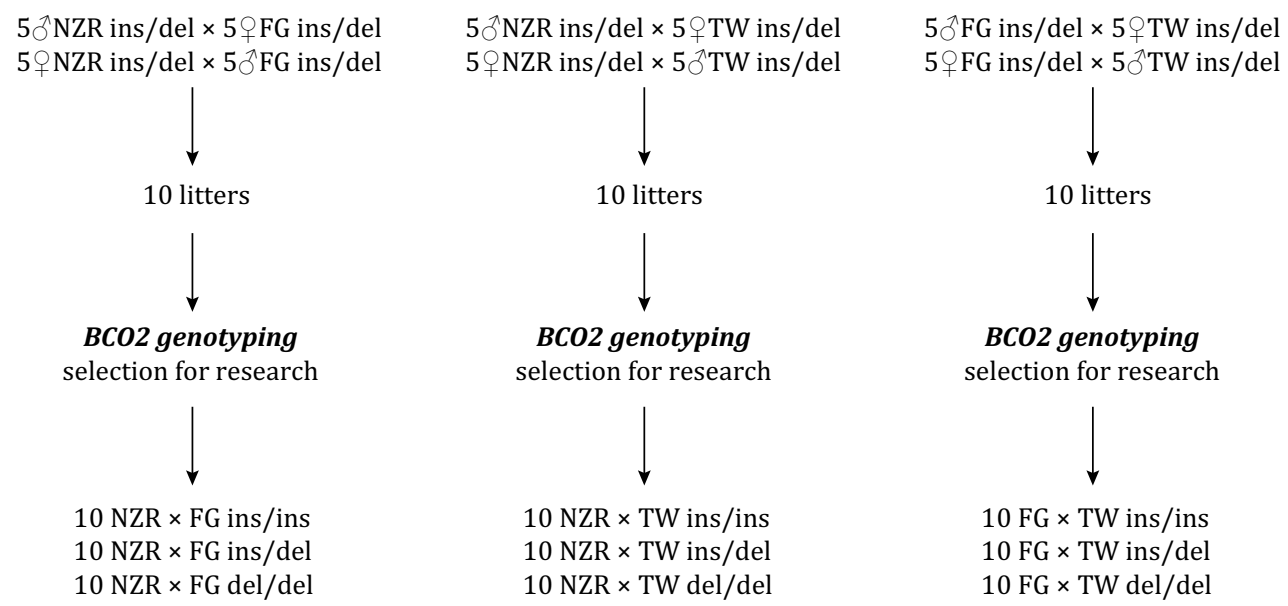

NZR - New Zealand Red rabbits; FG - Flemish Giant rabbits; TW - Termond White rabbits; ins - gene variant without AAT-deletion at codon 248 of the BCO2 gene; del - gene variant with the deletion.

Figure 1 - Mating scheme used to produce 90 rabbits of different genotypes at codon 248 of the BCO2 gene. 
Table 1 - Chemical composition and energy content of the feed

\begin{tabular}{lc}
\hline Item & \\
\hline Dry matter (\%) & 88.94 \\
Crude protein (\%) & 16.75 \\
Ether extract (\%) & 3.04 \\
Crude ash (\%) & 6.83 \\
Neutral detergent fiber (\%) & 27.91 \\
Acid detergent fiber (\%) & 18.63 \\
Lutein (mg/kg) & 37.70 \\
$\beta$-carotene (mg/kg) & 20.07 \\
Retinol (IU/kg) & 9174.00 \\
$\alpha$-tocopherol (mg/kg) & 32.36 \\
Gross energy (MJ/kg) & 17.28 \\
\hline
\end{tabular}

approximately $2 \mathrm{~min}$ ). After slaughter, the animals were skinned and eviscerated. Approximately $20 \mathrm{~g}$ samples of liver tissue and perirenal fat were collected for chemical analyses, and samples of perirenal fat were subjected to colorimetric analyses.

Rabbit carcasses were divided into "white fat" and "yellow fat" based on a visual assessment confirmed by colorimetric measurements $\left(\mathrm{L}^{*}, \mathrm{a}^{*}, \mathrm{~b}^{*}\right)$ performed with a portable MiniScan XE Plus system (HunterLab).

All chemical analyses were performed in duplicate.

Feed samples were assayed for the content of nutrients, by standard methods; dry matter, in a laboratory drier at $103{ }^{\circ} \mathrm{C}$; crude ash, by the sample mineralization in a muffle furnace (Czylok, Poland) at $600{ }^{\circ} \mathrm{C}$; total nitrogen, by the Kjeldahl method in a FOSS TECATOR Kjeltec 2200 Auto Distillation Unit; ether extract, by Soxhlet extraction in a FOSS SOXTEC SYSTEM 2043; neutral detergent fiber (NDF), according to the method proposed by Van Soest et al. (1991); acid detergent fiber (ADF), according to the official methods of analysis of Association of Official Analytical Chemists (AOAC, 2006) - these two (NDF and ADF), in a FOSS TECATOR Fibertec 2010 System; and gross energy, by using a bomb calorimeter (IKA ${ }^{\circledR} \mathrm{C} 2000$ basic, Germany).

The levels of retinol and $\alpha$-tocopherol in feed were determined in accordance with Polish Standards (Polish Standard PN-EN ISO 14565, 2002; Polish Standard PN-EN ISO 6867, 2002). Analytical samples of feed were saponified $\left(50 \% \mathrm{KOH}\right.$ in ethanol $\mathrm{w} / \mathrm{v}, 90^{\circ} \mathrm{C}, 30^{\prime}$, reflux condenser) and extracted with ethanol and petroleum ether. The extracts (upper fraction - hydrophobic ether extract; lower fraction - hydrophilic) were rinsed with $10 \%(\mathrm{w} / \mathrm{v})$ aqueous solution of $\mathrm{NaCl}$, then with distilled water, dehydrated with anhydrous sodium sulfate, and evaporated to dryness in the presence of nitrogen $\left(\mathrm{N}_{2}\right)$. The residue was dissolved in $96 \%$ ethanol to determine the content of tocopherols and retinol, and in $n$-hexane to determine the content of $\beta$-carotene and lutein. The samples were saponified at high temperature, which could contribute to the degradation of vitamin A, vitamin E (including retinol and $\alpha$-tocopherol), and carotenoids. However, according to Rodriguez-Bernaldo de Quirós and Costa (2006), high-temperature saponification facilitates the separation of analytes in samples with high lipid content (such as liver and adipose tissues) without the need for modifications in the chromatographic system (type and quantity of the mobile phase).

The concentrations of retinol and $\alpha$-tocopherol in animal tissues were determined as described by Högberg et al. (2002) and Xu (2008). One-gram samples of liver and adipose tissue were homogenized with $1.2 \mathrm{~cm}^{3}$ of $20 \%$ ascorbic acid in $\mathrm{H}_{2} \mathrm{O}$ (Ultra-Turrax T25 homogenizer, IKA Janke \& Kunkel, Germany) and saponified ( $375 \mathrm{~g} \mathrm{KOH}, 750 \mathrm{~cm}^{3} \mathrm{H}_{2} \mathrm{O}, 450 \mathrm{~cm}^{3}$ methanol, $80{ }^{\circ} \mathrm{C}, 15$ '). Ethanol (35\% v/v) and $\mathrm{NaCl}$ $(10 \% \mathrm{w} / \mathrm{v})$ were added to cooled samples, which were extracted twice with n-hexane $\left(2 \times 4 \mathrm{~cm}^{3}\right)$ and centrifuged (MPW - 350R centrifuge, Poland, $1500 \mathrm{~g}, 1^{\prime}$ ). We collected 3 and $4 \mathrm{~cm}^{3}$ of the supernatant, successively. The extracts were combined and evaporated under a nitrogen flux until drying. The residue was dissolved in $1 \mathrm{~cm}^{3}$ of $96 \%$ ethanol to determine the content of tocopherols and retinol, and in $\mathrm{n}$-hexane, to determine the content of $\beta$-carotene and lutein.

R. Bras. Zootec., 48:e20180243, 2019 
The concentrations of retinol and tocopherols in feed and animal tissues were determined by reversed-phase high-performance liquid chromatography (SHIMADZU-Japan; HPLC system), on a Nucleosil $\mathrm{C}_{18}$ column, with methanol/water (95:5, v:v) as the mobile phase, a UV detector $(326 \mathrm{~nm}$ for retinol) and a fluorescence detector (excitation - $295 \mathrm{~nm}$, emission - $330 \mathrm{~nm}$ for tocopherol). The levels of retinol and $\alpha$-tocopherol were measured by comparing their peak areas with those of external standards (Sigma-Aldrich; Germany: $( \pm)-\alpha$-tocopherol - No Cat. T3251, retinol - vitamin A - alcohol No Cat. R7632; $\alpha$-tocopherol recovery $-96 \pm 2.8 \%$, retinol recovery $-89 \pm 4.5 \%$ ).

The hexane extract of carotenoids was filtered through a $22 \mu \mathrm{m}$ PTFE syringe filter (30-SF-02 CHROMACOL Ltd.) and analyzed by RP-HPLC (SHIMADZU), column: Gemini $5 \mu \mathrm{m}$ (Phenomenex), $\mathrm{C}_{18}, 110 \AA \AA, 250 \times 4 \mathrm{~mm}$; mobilephase:methanol:tetrahydrofuran (95:5v/v) (HPLCgradeSIGMA-ALDRICH); flow rate: $1 \mathrm{~cm}^{3} \mathrm{~min}^{-1}$, detector: UV-vis $450 \mathrm{~nm}$; loop: $20 \mu \mathrm{L}$. External standard: $\beta$-carotene $(\beta$-carotene, provitamin A - No Cat. C4646; $\beta$-carotene recovery - 85\% $1.9 \%$ ) and xanthophyll (xanthophyll - lutein, $\alpha$-carotene-3,3'-diol; No Cat. X6250; xanthophyll recovery - 86 $\pm 6 \%)$ standards from Sigma-Aldrich (Germany) (Rodriguez-Bernaldo de Quirós and Costa, 2006).

In the tables, data are expressed as means \pm standard deviations (SD). Medians, 25th and 75th percentiles, and adjacent and outside values are presented in boxplots combined with stripcharts. The results were processed statistically using least squares means in GLM procedures. For comparison of specific $(n=10)$ and combined $(n=30)$ data, we used the same model:

$$
\mathrm{Y}_{\mathrm{ijk}}=\mu+\alpha_{\mathrm{i}}+\beta_{\mathrm{j}}+\alpha_{\mathrm{i}} \beta_{\mathrm{j}}+\varepsilon_{\mathrm{ij} \mathrm{k}^{\prime}}
$$

in which $\mu$ is the general mean, $\alpha_{i}$ is the effect of BCO2 genotype, $\beta_{i}$ is the effect of sex, $\alpha_{i} \beta_{i}$ is the interaction effect between genotype and sex, and $\varepsilon_{\mathrm{ijk}}$ is the random error. The significance of the differences among groups was determined with Duncan's multiple range test. Analyses did not reveal significant effects of sex or significant interactions between fixed effects, therefore they are not reported in the tables and figures. All calculations were performed using R Statistical software (R Core Team, 2015).

\section{Results}

The applied experimental design allowed to select 90 rabbits for the research. Within each mating scheme, 30 rabbits were obtained, including 10 animals of each genotype (ins/ins, ins/del, and del/del). After slaughter, the carcasses of rabbits were visually inspected, and it was found that all animals with the del/del genotype at codon 248 in $\mathrm{BCO} 2$ gene had yellow fat, whereas rabbits with ins/ins and ins/del genotypes had white fat (Figure 2). The results were confirmed by colorimetric analysis. In the group referred to as "white fat", the color coordinates of perirenal fat were as follows (mean \pm standard deviation): $L^{*}: 72.70 \pm 3.69, a^{*}: 5.61 \pm 1.27, b^{*}: 16.87 \pm 3.40$, and in the group classified as "yellow fat": $L^{*}: 60.82 \pm 4.25$, a*: 8.14 \pm 1.11 , and $b^{*}: 31.13 \pm 2.70$.

All crosses with the del/del genotype had higher concentrations of lutein than rabbits with ins/del and ins/ins genotypes (Table 2). No significant differences in lutein levels were found between the latter genetic groups. The $\mathrm{BCO} 2$ genotype had no influence on the levels of $\beta$-carotene, retinol, or $\alpha$-tocopherol.

In all three interbreed crosses, highly significant differences were found in lutein concentrations between rabbits with the del/del genotype vs. ins/del and ins/ins genotypes, whereas no differences in lutein content were noted between animals with ins/del and ins/ins genotypes (Table 3). In all mating schemes, $\beta$-carotene content was higher in rabbits with the del/del genotype than in those with the ins/ins genotype; $\beta$-carotene content was also higher in del/del NZR $\times$ FG and NZR $\times$ TW rabbits than in those with the ins/del genotype. In NZR $\times$ TW crosses, $\alpha$-tocopherol concentrations were higher in rabbits with the del/del genotype than in those with other genotypes.

The effect of the $\mathrm{BCO} 2$ genotype on the concentrations of the examined micronutrients was more pronounced and allowed to get more statistical power when all 90 samples were analyzed, irrespective of particular crosses (Figures 3 and 4 for the liver and adipose tissue, respectively).

R. Bras. Zootec., 48:e20180243, 2019 


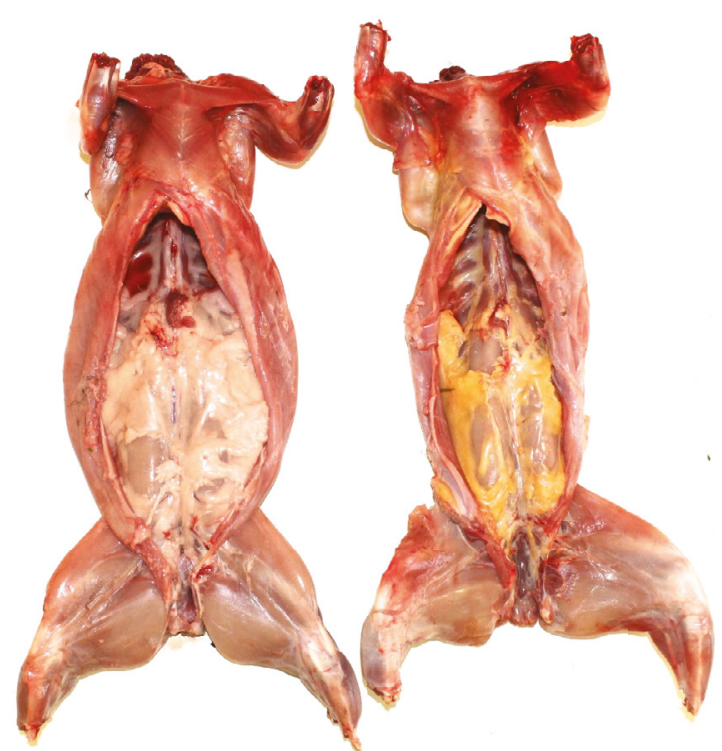

ins - gene variant without AAT-deletion at codon 248 of the BCO2 gene; del - gene variant with the deletion.

Figure 2 - Typical white- and yellow-fat phenotypes of rabbits associated with ins/ins or ins/del vs. del/del genotype at codon 248 of the BCO2 gene.
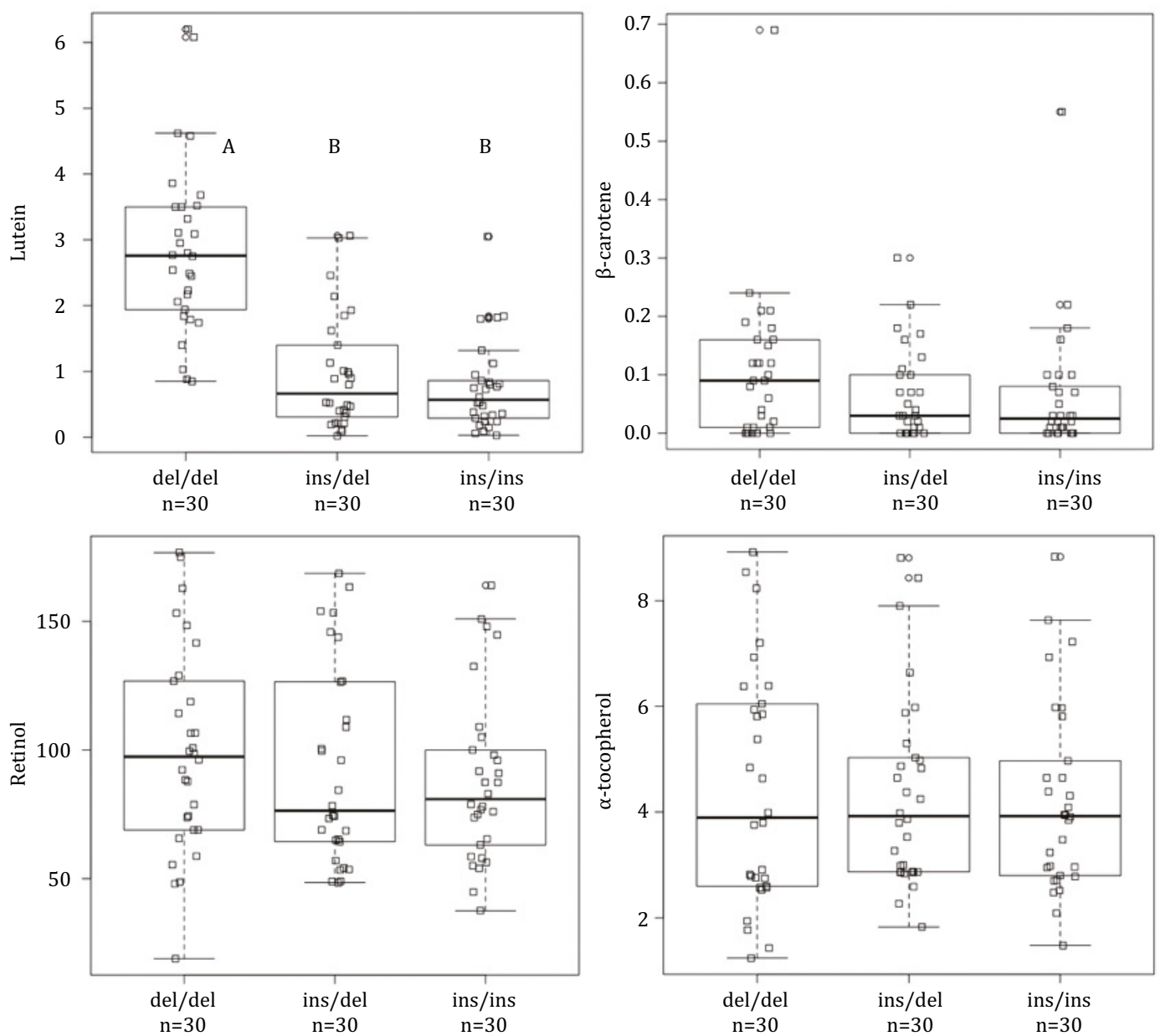

ins - gene variant without AAT-deletion at codon 248 of the BCO2 gene; del - gene variant with the deletion.

Means with different uppercase letters differ significantly at $\mathrm{P}<0.01$.

Figure 3 - Selected compounds ( $\mu \mathrm{g} / \mathrm{g}$ ) in the liver of rabbits (medians, 25th and 75th percentiles, and adjacent and outside values). 
Lutein concentrations were higher in homozygous del/del rabbits than in heterozygous ins/del and homozygous ins/ins individuals (medians 2.76, 0.67, and 0.57, respectively) (Figure 3). No significant differences in the levels of $\beta$-carotene, retinol, or $\alpha$-tocopherol were found between the groups.

Differences in the concentrations of lutein, $\beta$-carotene, and $\alpha$-tocopherol were found between the $\mathrm{del} / \mathrm{del}$ groups vs. ins/del and ins/ins groups, and the respective medians were $3.62,0.27$, and 0.23; $0.26,0.16$, and 0.13; and 3.93, 2.69, and 2.61 (Figure 4). Unlike in the liver, lutein levels in adipose tissue were always higher in rabbits with the del/del genotype than in those with ins/del and ins/ins genotypes. The levels of $\beta$-carotene and $\alpha$-tocopherol were lower in some individuals with the del/del genotype than in some individuals with ins/del and ins/ins genotypes.

\section{Discussion}

This is the first study to investigate the relationships between genotypes associated with the AAT in-frame deletion in the $\mathrm{BCO} 2$ gene and the presence of biologically active compounds in selected tissues of rabbits. This is also the first study of yellow fat performed on crossbred rabbits. There are three arguments to support the hypothesis that the AAT in-frame deletion in the $\mathrm{BCO} 2$ gene determines the presence of yellow fat in rabbits. Firstly, in all yellow-fat rabbits of three unrelated pure breeds (NZR, FG, and TW), this mutation was homozygous. Secondly, when purebred rabbits with the ins/del genotype at codon 248 were used for crossing, all crossbred rabbits with the del/del genotype had yellow fat,
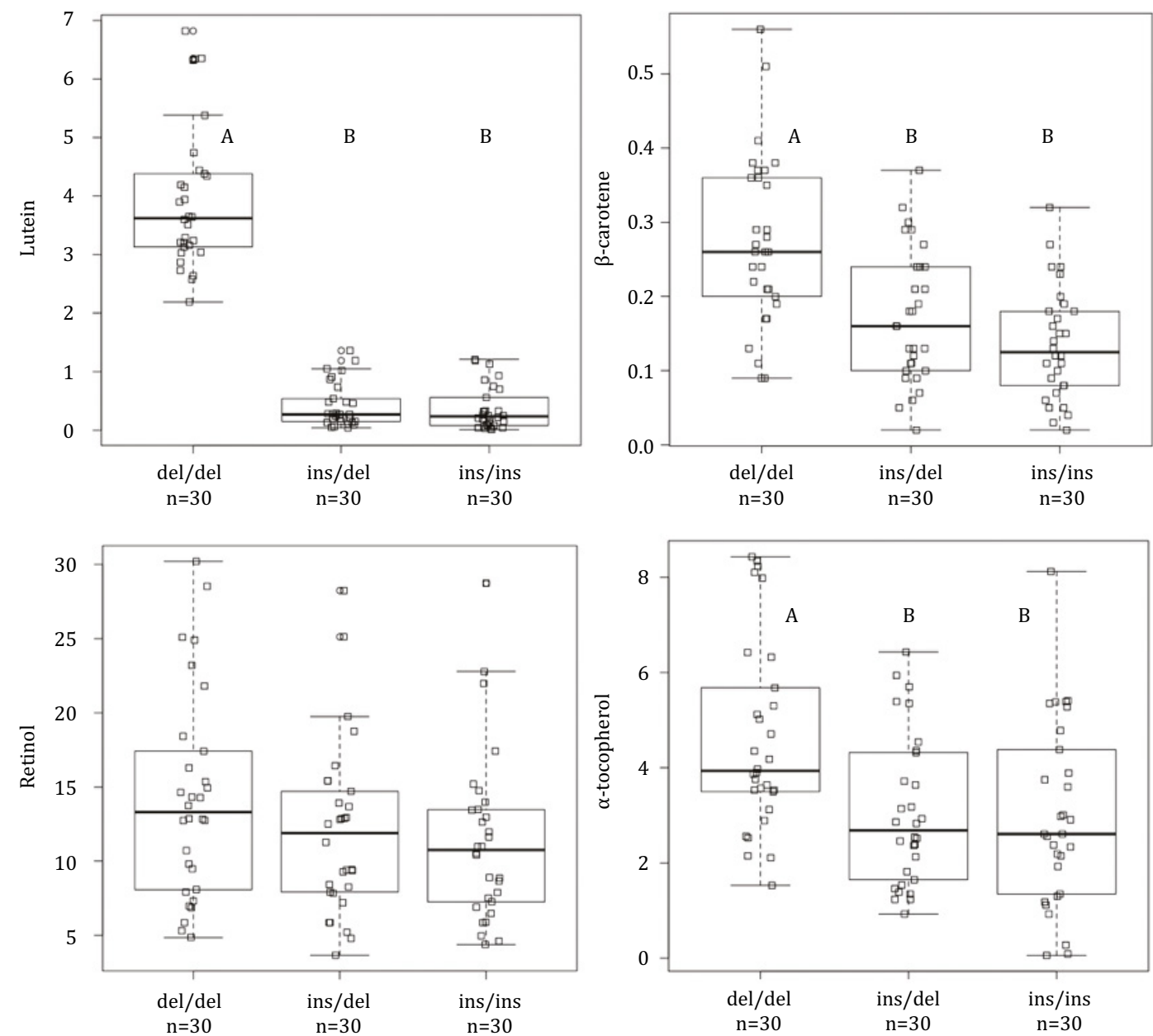

ins - gene variant without AAT-deletion at codon 248 of the BCO2 gene; del - gene variant with the deletion. Means with different uppercase letters differ significantly at $\mathrm{P}<0.01$.

Figure 4 - Selected compounds ( $\mu \mathrm{g} / \mathrm{g}$ ) in the perirenal fat of rabbits (medians, 25th and 75th percentiles, and adjacent and outside values). 
whereas all animals with ins/del and ins/ins genotypes had white fat, which was determined by a visual assessment (Figure 2) and confirmed by reflectance colorimetry. Thirdly, lutein concentrations in perirenal fat were always higher in homozygous rabbits carrying the AAT in-frame deletion than in the remaining individuals (Figure 4).

Xanthophylls and, to a much lesser extent, carotenes are responsible for the yellow color of fat (Bonet et al., 2015; Strychalski et al., 2016). The median value for lutein concentrations in fat reached $3.62 \mu \mathrm{g} / \mathrm{g}$ in homozygous del/del rabbits, and it was over 13 -fold higher than in rabbits with ins/del and ins/ins genotypes $(0.27$ and $0.23 \mu \mathrm{g} / \mathrm{g}$, respectively). The median values for $\beta$-carotene concentrations in fat were $0.26,0.16$, and $0.13 \mu \mathrm{g} / \mathrm{g}$, respectively, for $\mathrm{del} / \mathrm{del}$, ins/del, and ins/ins rabbits. The median noted in homozygous rabbits with the deletion was approximately two-fold higher than in the remaining animals.

Table 2 - Selected compounds $(\mu \mathrm{g} / \mathrm{g})$ in the liver of rabbits (mean $\pm \mathrm{SD})$

\begin{tabular}{|c|c|c|c|c|c|}
\hline & $\mathrm{n}$ & Lutein & $\beta$-carotene & Retinol & $\alpha$-tocopherol \\
\hline \multicolumn{6}{|l|}{$\mathrm{NZR} \times \mathrm{FG}$} \\
\hline ins/ins & 10 & $0.75 \pm 0.47 \mathrm{~B}$ & $0.08 \pm 0.17$ & $88.10 \pm 31.57$ & $3.68 \pm 1.56$ \\
\hline ins/del & 10 & $1.07 \pm 1.04 \mathrm{~B}$ & $0.08 \pm 0.11$ & $83.23 \pm 31.13$ & $4.27 \pm 2.07$ \\
\hline del/del & 10 & $3.25 \pm 1.60 \mathrm{~A}$ & $0.19 \pm 0.19$ & $101.59 \pm 40.19$ & $4.31 \pm 2.10$ \\
\hline P-value & & $<0.001$ & 0.186 & 0.478 & 0.721 \\
\hline \multicolumn{6}{|c|}{$\mathrm{NZR} \times \mathrm{TW}$} \\
\hline ins/ins & 10 & $0.91 \pm 0.92 \mathrm{~B}$ & $0.05 \pm 0.06$ & $94.15 \pm 32.36$ & $4.31 \pm 2.29$ \\
\hline ins/del & 10 & $1.17 \pm 0.91 \mathrm{~B}$ & $0.06 \pm 0.05$ & $106.21 \pm 41.59$ & $4.81 \pm 2.17$ \\
\hline del/del & 10 & $2.82 \pm 1.50 \mathrm{~A}$ & $0.08 \pm 0.08$ & $105.70 \pm 49.19$ & $5.00 \pm 2.33$ \\
\hline P-value & & 0.002 & 0.555 & 0.767 & 0.783 \\
\hline \multicolumn{6}{|l|}{$\mathrm{FG} \times \mathrm{TW}$} \\
\hline ins/ins & 10 & $0.58 \pm 0.56 \mathrm{~B}$ & $0.06 \pm 0.08$ & $81.73 \pm 36.59$ & $4.63 \pm 1.43$ \\
\hline ins/del & 10 & $0.63 \pm 0.55 \mathrm{~B}$ & $0.06 \pm 0.06$ & $88.63 \pm 41.88$ & $3.94 \pm 1.06$ \\
\hline del/del & 10 & $2.51 \pm 0.70 \mathrm{~A}$ & $0.05 \pm 0.05$ & $91.07 \pm 29.84$ & $4.02 \pm 2.35$ \\
\hline P-value & & $<0.001$ & 0.847 & 0.839 & 0.619 \\
\hline
\end{tabular}

NZR - New Zealand Red rabbits; FG - Flemish Giant rabbits; TW - Termond White rabbits; ins - gene variant without AAT-deletion at codon 248 of the BCO2 gene; del - gene variant with the deletion; SD - standard deviation.

Means within a column followed by different uppercase letters differ significantly at $\mathrm{P}<0.01$.

Table 3 - Selected compounds $(\mu \mathrm{g} / \mathrm{g})$ in the perirenal fat of rabbits $(\mathrm{mean} \pm \mathrm{SD})$

\begin{tabular}{|c|c|c|c|c|c|}
\hline & $\mathrm{n}$ & Lutein & $\beta$-carotene & Retinol & $\alpha$-tocopherol \\
\hline \multicolumn{6}{|l|}{$\mathrm{NZR} \times \mathrm{FG}$} \\
\hline ins/ins & 10 & $0.33 \pm 0.36 \mathrm{~B}$ & $0.13 \pm 0.09 \mathrm{~B}$ & $11.58 \pm 5.17$ & $2.79 \pm 2.01$ \\
\hline ins/del & 10 & $0.38 \pm 0.31 \mathrm{~B}$ & $0.16 \pm 0.09 b$ & $12.60 \pm 7.28$ & $2.86 \pm 1.41$ \\
\hline del/del & 10 & $3.62 \pm 1.17 \mathrm{~A}$ & $0.28 \pm 0.13 \mathrm{Aa}$ & $15.61 \pm 7.73$ & $4.48 \pm 1.72$ \\
\hline P-value & & $<0.001$ & 0.009 & 0.402 & 0.063 \\
\hline \multicolumn{6}{|c|}{$\mathrm{NZR} \times \mathrm{TW}$} \\
\hline ins/ins & 10 & $0.40 \pm 0.32 \mathrm{~B}$ & $0.15 \pm 0.07 \mathrm{~B}$ & $11.99 \pm 7.53$ & $2.86 \pm 1.54 \mathrm{~b}$ \\
\hline ins/del & 10 & $0.44 \pm 0.41 \mathrm{~B}$ & $0.20 \pm 0.10 \mathrm{~b}$ & $12.40 \pm 5.78$ & $2.98 \pm 1.77 b$ \\
\hline del/del & 10 & $3.96 \pm 1.06 \mathrm{~A}$ & $0.31 \pm 0.11 \mathrm{Aa}$ & $15.17 \pm 8.36$ & $4.79 \pm 1.96 a$ \\
\hline P-value & & $<0.001$ & 0.002 & 0.577 & 0.036 \\
\hline \multicolumn{6}{|l|}{$\mathrm{FG} \times \mathrm{TW}$} \\
\hline ins/ins & 10 & $0.37 \pm 0.45 \mathrm{~B}$ & $0.13 \pm 0.08 \mathrm{~b}$ & $10.65 \pm 4.35$ & $3.28 \pm 2.28$ \\
\hline ins/del & 10 & $0.43 \pm 0.43 \mathrm{~B}$ & $0.15 \pm 0.08$ & $10.94 \pm 4.24$ & $3.30 \pm 1.65$ \\
\hline $\mathrm{del} / \mathrm{del}$ & 10 & $4.22 \pm 1.46 \mathrm{~A}$ & $0.23 \pm 0.10 \mathrm{a}$ & $11.98 \pm 4.07$ & $4.56 \pm 2.48$ \\
\hline $\mathrm{P}$-value & & $<0.001$ & 0.030 & 0.761 & 0.333 \\
\hline
\end{tabular}

NZR - New Zealand Red rabbits; FG - Flemish Giant rabbits; TW - Termond White rabbits; ins - gene variant without AAT-deletion at codon 248 of the BCO2 gene; del - gene variant with the deletion; SD - standard deviation.

Means within a column followed by different letters differ significantly: lowercase at $\mathrm{P}<0.05$ and uppercase at $\mathrm{P}<0.01$. 
In sheep, similarly to rabbits, the presence of yellow fat is also associated with the storage of dietary carotenoids, mostly xanthophylls. In yellow-fat New Zealand sheep, the carotenoid content of perirenal fat ranged from $2.93 \mu \mathrm{g} / \mathrm{g}$ in lambs to $8.64 \mu \mathrm{g} / \mathrm{g}$ in wethers (Kirton et al., 1975). In yellow-fat Norwegian sheep, the carotenoid content of perirenal fat was $2.20 \mu \mathrm{g} / \mathrm{g}$ (Karijord, 1978). These differences may be related to the age of animals and the carotenoid content of their diets. The group of xanthophylls includes lutein, zeaxanthin, $\beta$-cryptoxanthin, capsantin, astaxanthin, and fucoxanthin. Crane and Clare (1975) found that yellow-fat sheep accumulate mostly lutein, a xanthophyll present in large quantities in green plants. Our study shows that, in adipose tissue of yellow-fat rabbits, large amounts of lutein are deposited. However, we did not search for wider array of xanthophylls. Furthermore, it is still unknown how the dietary carotenoids are chemically modified in rabbits.

Mice, for example, oxidize the 3-hydroxy groups of lutein and zeaxanthin (Amengual et al., 2011; Palczewski et al., 2016). Unlike in sheep and rabbits, a deleterious mutation in the bovine BCO2 gene, W80X, increases the levels of $\beta$-carotene but not of xanthophylls in adipose tissue, which becomes more reddish. Lower vitamin A levels in the liver were also reported in cattle. However, the W80X mutation only partially explains genetic variation in fat color in cattle (Berry et al., 2009). The fat color trait has also been found to be associated with polymorphism in the bovine RDHE2 (epidermal retinol dehydrogenase 2) gene, and other QTL are being identified (Tian et al., 2012).

In 160-day-old backcrossed yellow-fat NZR rabbits fed diets containing $82.41 \mathrm{mg} / \mathrm{kg}$ of lutein and $24.53 \mathrm{mg} / \mathrm{kg}$ of $\beta$-carotene, the concentrations of lutein and $\beta$-carotene in fat were $5.01 \mu \mathrm{g} / \mathrm{g}$ and $1.63 \mu \mathrm{g} / \mathrm{g}$, respectively. The noted values were 13- and three-fold higher, respectively, than those determined in white-fat rabbits (Strychalski et al., 2016). In the present study, the levels of lutein and $\beta$-carotene in the fat of rabbits were generally lower, which could result from their lower dietary content and a shorter fattening period ( $140 \mathrm{~d}$ ). However, a similar relationship between the levels of lutein and $\beta$-carotene was noted in yellow-fat and white-fat rabbits. This is consistent with the observation that the expression and activities of $\mathrm{BCO} 1$ and $\mathrm{BCO} 2$ enzymes are complementary. Most of the absorbed $\beta$-carotene is cleaved by $\mathrm{BCO} 1$, whereas the rest can be cleaved by $\mathrm{BCO} 2$ or accumulated in adipose tissue (Lietz et al., 2010). Thus, in the case of functional impairment of BCO2, an increase in xanthophyll concentrations should be accompanied by an increase in $\beta$-carotene levels. The above was observed in each mating scheme (Table 3 ) and across all groups (Figure 4).

Since $\beta$-carotene is a precursor of vitamin A, its greater accumulation in the body can stimulate the production of vitamin $A$ and its storage in adipose tissue. Moreover, $\beta$-carotene can be used instead of vitamin $A$ - it has been reported that the activity of $12 \mu \mathrm{g}$ of $\beta$-carotene is comparable with that of $1 \mu \mathrm{g}$ of vitamin A (Weber and Grune, 2012). In a previous experiment, retinol levels were higher in yellow-fat rabbits than in white-fat rabbits - 53.99 vs. $36.01 \mu \mathrm{g} / \mathrm{g}$ (Strychalski et al., 2016). However, in the present study, no significant differences in retinol concentrations in fat were found between the groups (median values of 10.76 to $13.31 \mu \mathrm{g} / \mathrm{g}$ ).

Retinol levels have been rarely analyzed in rabbits. In comparison with our results, Yap et al. (1997) reported considerably lower retinol concentrations in the liver and fat of rabbits $(0.30-1.15 \mu \mathrm{g} / \mathrm{g}$ and 0.01-0.07 $\mu \mathrm{g} / \mathrm{g}$, respectively). In a study by Zanutto et al. (2003), retinol levels in the liver of rabbits ranged from 2.01 to $54.19 \mu \mathrm{g} / \mathrm{g}$. Both cited studies investigated the effect of $\beta$-carotene levels in experimental diets on the concentrations of several forms of vitamin A in rabbit tissues. Commercial diets are often supplemented with vitamin and mineral premixes that may contain up to $1,000,000 \mathrm{IU} / \mathrm{kg}$ of vitamin A (Gugołek et al., 2015). The addition of $1 \%$ of the premix to the diet corresponds to 10,000 IU of vitamin A per kg of feed. In the present experiment, $1 \mathrm{~kg}$ of feed contained 9,174 IU of vitamin A.

As expected, average lutein levels in the liver were higher in yellow-fat rabbits than in white-fat rabbits, because the former were unable to break down this xanthophyll. A similar observation was made in backcrossed NZR rabbits (Strychalski et al., 2016). However, in both experiments, hepatic $\beta$-carotene levels were comparable in yellow-fat and white-fat rabbits. In view of the fact that $\beta$-carotene levels in perirenal fat were approximately six- (Strychalski et al., 2016) and two-fold higher (present experiment) 
in yellow-fat rabbits than in white-fat rabbits, the above similarities seem surprising. However, this provides further evidence that mutation in the $\mathrm{BCO} 2$ gene in rabbits directly affects xanthophyll metabolism and indirectly influences $\beta$-carotene metabolism. It is worth mentioning that, similar to rabbits, no significant differences in hepatic $\beta$-carotene levels were observed between wild type and BCO2-deficient mice, either (Amengual et al., 2013).

Apart from retinol, we also measured the levels of $\alpha$-tocopherol, because both vitamins A and E are non-enzymatic components of the antioxidant defense system (Zwolińska et al., 2006). In the previous experiment, we observed that the concentrations of retinol and $\alpha$-tocopherol in fat of yellow-fat rabbits increased, compared with white-fat rabbits (Strychalski et al., 2016). Therefore, it seems surprising that in the present study, an increase in $\alpha$-tocopherol concentrations in the perirenal fat of yellow-fat rabbits was not accompanied by an increase in retinol levels (Figure 4). The relationship between vitamin $\mathrm{A}$ and vitamin $\mathrm{E}$ levels in animals remains insufficiently researched; however, as demonstrated by Napoli et al. (1984) on rats, $\alpha$-tocopherol may play a role in tissue retinol homeostasis.

Experimental rabbits were fed commercial complete diets. They were slaughtered at 140 days of age to reveal the genetically determined differences in levels of carotenoids. For economic reasons, commercially bred hybrid rabbits (e.g., ZiKa and Hyplus) are slaughtered before 90 days of age (Dänicke at al., 2004; Gugołek et al., 2017), which could be a period too short for carotenoids to reach satisfactory levels in animal tissues. To date, conventional and organic farming systems have not yet been replaced by commercial rabbit breeding. On many small backyard farms, animals are fed fresh green forage, which has higher carotenoid content than commercial complete diets (Perry et al., 2009), and the rearing period is longer, particularly in large rabbit breeds such as the widely used FG (Strychalski et al., 2014). Further research should focus on determining the rate of carotenoid accumulation in the fat of rabbits with various genotypes at codon 248 of the BCO2 gene, in view of different carotenoid concentrations in feed.

\section{Conclusions}

Polymorphism BCO2 differentiates lutein content in the liver and the concentrations of lutein, $\beta$-carotene, and $\alpha$-tocopherol in perirenal fat in various crossbred rabbits. Lutein concentration in fat is over 13-fold higher in rabbits carrying a homozygous AAT-deletion than in the remaining animals. A codon deletion in the $\mathrm{BCO} 2$ gene also contributes to an increase in concentrations of $\beta$-carotene and $\alpha$-tocopherol in the adipose tissue of rabbits. However, no differences are observed in the content of the analyzed components between heterozygous and homozygous rabbits without the deletion.

\section{References}

Amengual, J.; Lobo, G. P.; Golczak, M.; Li, H. N. M.; Klimova, T.; Hoppel, C. L.; Wyss, A.; Palczewski, K. and von Lintig, J. 2011. A mitochondrial enzyme degrades carotenoids and protects against oxidative stress. The FASEB Journal 25:948-959. https://doi.org/10.1096/fj.10-173906

Amengual, J.; Widjaja-Adhi, M. A. K.; Rodriguez-Santiago, S.; Hessel, S.; Golczak, M.; Palczewski, K. and von Lintig, J. 2013. Two carotenoid oxygenases contribute to mammalian provitamin A metabolism. Journal of Biological Chemistry 288:34081-34096. https://doi.org/10.1074/jbc.M113.501049

AOAC - Association of Official Analytical Chemists. 2006. Official methods of analysis. 18th ed. Association of Analytical Communities, Arlington, VA, USA.

Berry, S. D.; Davis, S. R.; Beattie, E. M.; Thomas, N. L.; Burrett, A. K.; Ward, H. E.; Stanfield, A. M.; Biswas, M.; Ankersmit-Udy, A. E.; Oxley, P. E.; Barnett, J. L.; Pearson, J. F.; van der Does, Y.; MacGibbon, A. H. K.; Spelman, R. J.; Lehnert, K. and Snell, R. G. 2009. Mutation in bovine $\beta$-carotene oxygenaze 2 affects milk color. Genetics 182:923-926.

Bonet, M. L.; Canas, J. A.; Ribot, J. and Palou, A. 2015. Carotenoids and their conversion products in the control of adipocyte function, adiposity and obesity. Archives of Biochemistry and Biophysics 572:112-125. https://doi.org/10.1016/j.abb.2015.02.022

Crane, B. and Clare, N. T. 1975. Nature of carotenoid pigments in yellow fat of sheep. New Zealand Journal of Agricultural Research 18:273-275. https://doi.org/10.1080/00288233.1975.10423644

R. Bras. Zootec., 48:e20180243, 2019 
Dänicke, S.; Ahrens, P.; Strobel, E.; Brettschneider, J.; Wicke, M. and von Lengerken, G. 2004. Effects of feeding rapeseed to fattening rabbits on performance, thyroid hormone status, fatty acid composition of meat and other meat quality traits. Archiv fur Geflugelkunde 68:15-24.

Gugołek, A.; Juśkiewicz, J.; Wyczling, P.; Kowalska, D.; Strychalski, J.; Konstantynowicz, M. and Zwoliński, C. 2015. Productivity results and physiological response of the gastrointestinal tract of rabbits fed diets containing rapeseed cake and wheat distillers dried grains with solubles. Animal Production Science 55:777-785. https://doi.org/10.1071/AN14206

Gugołek, A.; Juśkiewicz, J.; Strychalski, J.; Zwoliński, C.; Żary-Sikorska, E. and Konstantynowicz, M. 2017. The effects of rapeseed meal and legume seeds as substitutes for soybean meal on productivity and gastrointestinal function in rabbits. Archives of Animal Nutrition 71:311-326. https://doi.org/10.1080/1745039X.2017.1322796

Högberg, A.; Pickova, J.; Babol, J.; Andersson, K. and Dutta, P. C. 2002. Muscle lipids, vitamins E and A, and lipid oxidation as affected by diet and RN genotype in female and castrated male Hampshire crossbreed pigs. Meat Science 60:411-420. https://doi.org/10.1016/S0309-1740(01)00153-X

Karijord, 0. 1978. Correlation between content of carotenoids in depot fat and plasma of sheep. Acta Agriculturae Scandinavica 28:355-359. https://doi.org/10.1080/00015127809435192

Kirton, A. H.; Crane, B.; Paterson, D. J. and Clare, N. T. 1975. Yellow fat in lambs caused by carotenoid pigmentation. New Zealand Journal of Agricultural Research 18:267-272. https://doi.org/10.1080/00288233.1975.10423643

Kotake-Nara, E. and Nagao, A. 2011. Absorption and metabolism of xanthophylls. Marine Drugs 9:1024-1037. https://doi.org/10.3390/md9061024

Lietz, G.; Lange, J. and Rimbach, G. 2010. Molecular and dietary regulation of $\beta, \beta$-carotene 15, 15 '-monooxygenase 1 (BCM01). Archives of Biochemistry and Biophysics 502:8-16. https://doi.org/10.1016/j.abb.2010.06.032

Lietz, G.; Oxley, A.; Boesch-Saadatmandi, C. and Kobayashi, D. 2012. Importance of $\beta, \beta$-carotene15,15'-monooxygenase 1 (BCMO1) and $\beta, \beta$-carotene 9',10'-dioxygenase 2 (BCD02) in nutrition and health. Molecular Nutrition \& Food Research 56:241-250. https://doi.org/10.1002/mnfr.201100387

Mein, J. R.; Dolnikowski, G. G.; Ernst, H.; Russell, R. M. and Wang, X. D. 2011. Enzymatic formation of apo-carotenoids from the xanthophyll carotenoids lutein, zeaxanthin and $\beta$-cryptoxanthin by ferret carotene-9',10'-monooxygenase. Archives of Biochemistry and Biophysics 506:109-121. https://doi.org/10.1016/j.abb.2010.11.005

Napoli, J. L.; McCormick, A. M.; O'Meara, B. and Dratz, E. A. 1984. Vitamin A metabolism: $\alpha$-tocopherol modulates tissue retinol levels in vivo, and retinyl palmitate hydrolysis in vitro. Archives of Biochemistry and Biophysics 230:194-202. https://doi.org/10.1016/0003-9861(84)90100-0

Palczewski, G.; Widjaja-Adhi, M. A. K.; Amengual, J.; Golczak, M. and von Lintig, J. 2016. Genetic dissection in a mouse model reveals interactions between carotenoids and lipid metabolism. Journal of Lipid Research 57:1684-1695. https://doi.org/10.1194/jlr.M069021

Perry, A.; Rasmussen, H. and Johnson, E. J. 2009. Xanthophyll (lutein, zeaxanthin) content in fruits, vegetables and corn and egg products. Journal of Food Composition and Analysis 22:9-15. https://doi.org/10.1016/j.jfca.2008.07.006

Polish Standard PN-EN ISO 6867. 2002. Feedstuffs. Determination of vitamin E by high-performance liquid chromatography. Polish Standard PN-EN ISO 14565. 2002. Feedstuffs. Determination of vitamin A by high-performance liquid chromatography.

R Core Team. 2015. R: A language and environment for statistical computing. R Foundation for Statistical Computing, Vienna, Austria. Available at: <https://www.R-project.org/>. Accessed on: Dec. 18, 2015.

Rodriguez-Bernaldo de Quirós, A. and Costa, H. S. 2006. Analysis of carotenoids in vegetable and plasma samples: A review. Journal of Food Composition and Analysis 19:97-111. https://doi.org/10.1016/j.jfca.2005.04.004

Strychalski, J.; Gugołek, A.; Daszkiewicz, T.; Konstantynowicz, M.; Kędzior, I. and Zwoliński, C. 2014. A comparison of selected performance indicators, nutrient digestibility and nitrogen balance parameters in Californian and Flemish Giant rabbits. Journal of Applied Animal Research 42:389-394. https://doi.org/10.1080/09712119.2013.875905

Strychalski, J.; Brym, P.; Czarnik, U. and Gugołek, A. 2015. A novel AAT-deletion mutation in the coding sequence of the BCO2 gene in yellow-fat rabbits. Journal of Applied Genetics 56:535-537. https://doi.org/10.1007/s13353-015-0290-9

Strychalski J.; Gugołek, A.; Antoszkiewicz, Z.; Kowalska, D. and Konstantynowicz, M. 2016. Biologically active compounds in selected tissues of white-fat and yellow-fat rabbits and their production performance parameters. Livestock Science 183:92-97. https://doi.org/10.1016/j.livsci.2015.11.024

Tian, R.; Pitchford, W. S.; Morris, C. A.; Cullen, N. G. and Bottema, C. D. K. 2010. Genetic variation in the $\beta, \beta$-carotene 9', 10'-dioxygenase gene and association with fat colour in bovine adipose tissue and milk. Animal Genetics 41:253-259. https://doi.org/10.1111/j.1365-2052.2009.01990.x

Tian, R.; Cullen, N. G.; Morris, C. A.; Fisher, P. J.; Pitchford, W. S. and Bottema, C. D. K. 2012. Major effect of retinal short-chain dehydrogenase reductase (RDHE2) on bovine fat colour. Mammalian Genome 23:378-386 https://doi.org/10.1007/s00335-012-9396-0

R. Bras. Zootec., 48:e20180243, 2019 
Van Soest, P. J.; Robertson, J. B. and Lewis, B. A. 1991. Methods for dietary fibre, neutral detergent fibre and nonstarch polysaccharides in relation to animal nutrition. Journal of Dairy Science 74:3583-3597. https://doi.org/10.3168/jds.S0022-0302(91)78551-2

Våge, D. I. and Boman, I. A. 2010. A nonsense mutation in the beta-carotene oxygenase 2 (BCO2) gene is tightly associated with accumulation of carotenoids in adipose tissue in sheep (Ovis aries). BMC Genetics 11:10. https://doi.org/10.1186/1471-2156-11-10

Weber, D. and Grune, T. 2012. The contribution of $\beta$-carotene to vitamin A supply of humans. Molecular Nutrition \& Food Research 56:251-258. https://doi.org/10.1002/mnfr.201100230

$\mathrm{Xu}, \mathrm{Z}$. 2008. Comparison of extraction methods for quantifying vitamin E from animal tissues. Bioresource Technology 99:8705-8709. https://doi.org/10.1016/j.biortech.2008.04.065

Yap, S. C.; Choo, Y. M.; Hew, N. F. and Goh, S. H. 1997. Distribution of dietary palm carotenes and their metabolites in the rabbit. Nutrition Research 17:1721-1731. https://doi.org/10.1016/S0271-5317(97)00178-4

Zanutto, M. E.; Jordão Jr., A. A. and Vannucchi, H. 2003. Improvement in vitamin A status with consumption of dark-green vegetables - a bioavailability study in rabbits. Nutrition Research 23:271-278. https://doi.org/10.1016/S0271-5317(02)00497-9

Zwolińska, D.; Grzeszczak, W.; Szczepańska, M.; Kiliś-Pstrusińska K. and Szprynger, K. 2006. Vitamins A, E and C as non-enzymatic antioxidants and their relation to lipid peroxidation in children with chronic renal failure. Nephron Clinical Practice 103:12-18. https://doi.org/10.1159/000090506 